\title{
Ethics and Professional Commitment: The Perceptions of Professionals and Accounting Students
}

\author{
TÂNIA ALVES DE JESUS
}

Lisbon Accounting and Business School

Email: tajesus@iscal.ipl.pt

Tel: +351217984500

JULIETA AZEVEDO

Lisbon Accounting and Business School Email: mjazevedo@iscal.ipl.pt

Tel: +351217984500

\section{VERA PINTO}

Lisbon Accounting and Business School

Email: vcpina@iscal.ipl.pt

Tel: +351217984500

\section{JÉSSICA JOÃO ALVES}

Lisbon Accounting and Business School Email: jessicalves_28@ hotmail.com Tel: +351217984500

\begin{abstract}
Accounting professionals face daily dilemmas and challenges in the exercise of their activity. This situation results from several factors, for example, the constant changes in the tax system and the overgrowing requirements to fulfil the national tax authority obligations. There is a market saturation regarding the number of accounting professionals and the low business creation rate in Portugal. These factors minimize and depreciate the accounting career leading it to be underestimated by the society. This research studies the relations between professional ethics, professional commitment and society's recognition regarding the certified accountant profession, among accounting professionals and accounting students (future professionals), and confronting their perceptions. It was possible to verify that professional ethics influences the commitment in the accounting profession, the higher the level of ethics is, the higher is the professional commitment. The results suggest that society recognition influences professional commitment, since the more recognition is felt by the individuals, the greater is their professional commitment and the higher is the recognition by society, greater is their professional ethics. In the confrontation, between professional and future professionals perceptions, there were no significant divergences regarding professional ethics and professional commitment. However, it was verified that, from the professionals' point of view, the level of recognition by the society is inferior to the one presented by the students.
\end{abstract}

Keywords: Ethics, Deontology, Accounting, Professional commitment, Morality. 


\section{Introduction}

This study focus on professional ethics and some of its surroundings, which has become an increasingly relevant issue in the society. Following the emergence of various financial scandals, society has been aroused to the importance of good practices in the business sciences, especially in accounting (Moreira et.al., 2017). Professional ethics in the field of accounting has been investigated from the perspective of accounting professionals and from the perspective of accounting students. However, an analysis comparing and relating both perceptions, taking into consideration professional ethics in the practice of certified accountancy, is interesting.

Accounting professionals and students are at different times in their career path. Professionals are individuals who have professional experience in accounting, including certified accountants. Future professionals include accounting students and other students in related areas. The main objectives of this research are to investigate the perception of accountants and future professionals in the field of professional ethics related to the accounting profession and to contribute to the literature in accounting ethics. Through the analysis of two different groups, accounting professionals and students who correspond to future professionals it is possible to identify two perspectives and ascertain the divergences between them.

\section{Ethics, Morality and Deontology}

The object of study of ethics is the observation of human behavior in the social or professional context. Morality consists of the set of conduct and norms considered accepted in a given society. Deontology is a discipline of ethics applied to the practice of the profession.

The expression "ethics" has a Greek origin ethos which means character. According to Arruda, Whitaker, and Ramos (2001, p. 42) "Ethics is the part of philosophy that studies the morality of human action; that is, it considers human acts as good or bad". Ethics belongs to the personal sphere, that is, each individual distinguishes between good and evil and is aware of the possible consequences of their actions. Thus, codes of ethics are not intended to solve ethical dilemmas, but to provide criteria or guidelines for people to discover ethical ways to follow.

The concept of moral is broader than the concept of ethics because it submits to a value established by the norms, laws and customs of society. Laws consist of a norm or set of legal norms developed through the processes proper to the normative act and established by the competent authorities. The customs consist of social rules resulting from a generalized and prolonged repeated practice, resulting in a certain conviction of obligation, according to each society and culture. The term "deontology" comes from the Greek words don and donts, translated correspond to duty and logos, which means science. Deontology is a discipline of ethics oriented towards the profession, thus defining deontology the ethics applied to a professional activity (Gonçalves \& Carreira, 2012).

Ethics is applied in various aspects in society, considering that it is governed by laws and customs. Laws and customs aim to ensure order in the coexistence between citizens. In this sense, ethics influences all decisions within the organization, so companies seek to formalize and develop their code of ethics. This code aims to guide and guide the behavior of everyone involved in the company (Chiavenato, 2004). The concept of organizations' code of ethics is defined by a document that has the principles and norms that convey organizational values to different stakeholders. Thus, the code establishes the principles and limits in the relationship with each stakeholder (Vargas, 2005). The term 'code of ethics' is generally applied to professions and the codes of professional ethics aim to implement and foster more ethical attitudes towards the exercise of their profession. According to Gonçalves and Carreira (2012, p. 26), "[...] the codes of professional ethics list assertions about general ethical principles and particular rules about problems that arise in daily professional action". 


\section{Ethics in Professional Activity}

Ethics in professional activity correspond to the set of attitudes and values applied in the workplace. Professional ethics is essential for the proper functioning of the organization's activities and working relationships. In the last two decades several publications of codes of conduct or conduct regarding professions and activities have emerged (Gonçalves \& Carreira, 2012).

Ethical decision-making is a process that results from the identification of an ethical problem, the creation of choices and the selection of one that will maximize the fundamental moral values of the individual, and simultaneously the intended goal. Business decision-making models aim to define the core aspects of an individual's ethical behavior. The position of the professional is influenced by factors regarding the ethical dilemmas that result from the professional activity, and in turn in the perception about the norms of the code of ethics (Alves, Weffort \& Antunes, 2007).

The ethics of the professional activity of accounting in Portugal is delimited by the Statute of the Order of Certified Accountants (OCC) and the Code of Ethics of Certified Accountants.

\section{Certified Accountants}

The OCC is a public institution representing professionals. The Order aims to regulate and discipline the profession of Certified Accountant in its exercise, promoting the credibility of the profession and to establish the legal regime for the creation, organization and operation of professional public associations. This defines the governing bodies in their composition, competence and term of office.

The profession of Certified Accountant is defined in the following manner:

[d] Certified accountants are designated professionals registered with the Order, under the terms of the present Statute, being exclusively assigned the use of this professional title, as well as the exercise of their profession (Decree Law No 139/2015).

Currently, the profession of certified accountant is recognized and considered in the public interest, having several credibility factors in its exercise. Certified accountants are responsible for verifying that the financial statements have a true and fair view of the transactions that occur in a respective entity. Thus the obligation of an ethical attitude in the preparation and disclosure of the financial statements becomes essential. As stated in the Conceptual Framework of the Accounting Standardization System, it is assumed that the information in the financial statements is useful for economic decision making to meet the needs of users.

Certified accountants have a set of rights over third parties, clients, colleagues and the company. The deontological code of certified accountants aims to establish a set of ethical principles and deontological conduct. These principles correspond to the values that professionals consider fundamental for the exercise of the profession. These ethical principles, conduct and professional values correspond to the ideal to be achieved. Thus these deontological principles aim to foster professional awareness of accountability standards; define assertions about general ethical principles and particular rules about concrete situations in the practice of the profession; and suppress unethical procedures (Gonçalves, Gonçalves \& Sequeira, 2014).

Certified Accountants' Code of Ethics addresses the general duties in the exercise of the profession of certified accountant. Certified accountants must comply with the applicable accounting and tax rules applicable to the client's situation. Correct application of the legal (accounting and tax) rules gives the financial statements a true and fair view and requires the certified accountant to be intolerant of personal or third party pressure. It presents the principles of professional ethics by professionals, namely: integrity principle, integrity principle, independence principle, principle of responsibility, principle of competence, 
principle of confidentiality, principle of fairness and the principle of loyalty. These principles are interconnected, thus influencing the competency and performance of the professional. Therefore, the deontological principles and duties of certified accountants as a whole constitute the action guide of the certified accountant's action.

\section{Research design}

This study aims to evaluate the perceptions and expectations between accounting professionals and future professionals, within the scope of professional ethics regarding the profession of Certified Accountant. Given that two different perspectives are to be compared, the empirical study was applied to accounting professionals (Certified Accountants or not) and future accounting professionals (students in courses directly related to the area of accounting). The hypothesis defined was the following:

Hypothesis: Accounting professionals and future professionals have different perceptions about professional ethics in accounting.

\section{Research Methodology}

The data collection method for this research was on the form of survey conducted by applying the questionnaire. The final questionnaire was reached, which consists of 40 questions of a quantitative nature. The questionnaire was structured in two parts, the first part corresponds to the characterization of the respondent and the second part covers ethics and professional commitment. The purpose of this last part was to study the level of professional commitment and professional ethics of the sample under study, using a scale from 1 to "strongly disagree" and 5 to "totally agree". Since for this article only the aspect of professional ethics is analyzed.

There are distinct populations present in the research: the population of accounting professionals (who have professional experience in accounting, including Certified Accountants) and the population of accounting students or related areas (corresponding to future accounting professionals).

In the process of data collection for the research, professionals were distributed questionnaires in professional training in accounting and also by publishing the questionnaire online during the year of 2016. Regarding future accounting professionals, the individuals under study focus mainly on students from the Lisbon Institute of Accounting and Administration, covering the academic years 2015/2016 and 2016/2017. The sample was divided between accounting professionals and future professionals according to Scheme 1 . This distinction occurs in question 'A4. Do you attend a higher education course in the current school year?', With students answering the 'yes' option and professionals answering the 'no' option.

Accounting professionals were distinguished between those who have professional experience in accounting and those who do not yet have any experience. This framework follows from the question 'A5. How many years of professional experience do you have in accounting?', The 'no experience' option and the rest with number of years. Since only professionals without any professional experience in accounting do not fit this investigation, therefore they were excluded from it. Prospective accounting professionals correspond to students who attend a higher education course in the 2015/2016 or 2016/2017 academic years (explicitly stated in question A4.) And who do not have professional experience in accounting (arising from question A5.). However, students with professional experience fall into the group of accounting professionals.

\section{Results of the Empirical Study}

It was obtained 608 answered questionnaires and from the total, 9 questionnaires were excluded (without experience and professional knowledge in accounting). Thus, 599 questionnaires were analyzed. Of the 
responses obtained regarding age, about 323 (54\%) fall between the ages of 20 and 29. It can be seen that the sample is diverse in terms of covering all age groups of working life, with the youngest respondent being 18 years old and the oldest being 72 years old. Thus, of the 599 responses obtained, about 363 respondents are women (61\% of the sample) and the remaining 236 men (39\% of the sample). Graph 3 shows that about $64 \%$ (381 respondents) have completed upper secondary education. This is because undergraduate students have a significant weight in research. Respondents who hold a degree represent $30 \%$ of the sample, 179 individuals.

The sample consists of $71 \%$ of respondents attending a course in higher education in the 2015/2016 school year or 2016/2017, corresponding to 426 individuals. The remaining respondents indicated that they did not attend any higher education course in the corresponding school year. In this sense, the 426 respondents who attend higher education fall within the scope of students. From the analysis of graph 5, respondents' courses fall into the following areas: accounting, management, finance and others. Of the 580 answers obtained, 387 individuals attend or have attended the accounting course. About 135 individuals fall into the area of management.

The ethics in the accounting profession will be verified through hypothesis 1 'accounting professionals and future professionals present different perceptions about professional ethics in accounting'. In this context they have been analyzed since statement 1 to 13 , from which eight statements have been selected for analysis (B.2., B.3., B.4., B.5., B.7. B.11., B.12. and B.13.).

\section{B.2. The accountant can practice the profession based on standards of honesty and good faith.}

The average value of professionals is 4.01 and the average value of students is 3.90 . Accounting students have a higher standard deviation than that of accounting professionals, thus resulting in a greater dispersion of response among students. Accounting professionals and prospective professionals have slightly divergent views. For professionals, the accountant is more likely to practice the profession based on standards of honesty and good faith than on students' perceptions.

\section{B.3. The accountant can only accept jobs he feels fit to perform.}

Professionals have an average response in the 'partially agree' option (3.62) and future professionals have an average in the 'disagree or disagree' option (3.47). The standard deviations of both groups are similar, since the obtained answers are dispersed by the existing options. In this mode, the perceptions of the groups tend to differ. The confidence interval (95\%) of both groups is between option 3 and option 4 . From the professional's point of view, the accountant can accept more work that he or she feels able to perform than students consider.

\section{B.11. Since I entered accounting, my values and those of the profession have been approaching.}

The average accounting professional is 3.08 and the average student is 2.72 . The standard deviation of accounting professionals is 0.829 and the standard deviation of students is 0.899 , and the level of dispersion between groups is similar. Confidence levels (95\%) of accounting professionals and students are in the 'partially or often agree' option. Accounting professionals and prospective professionals have tendingly divergent perceptions. From the perspective of accounting professionals, their personal values have been closer to those of the profession since they entered the field than from the perspective of accounting students.

\section{B.12. Sometimes in the profession of accountant it is necessary to circumvent the rules.}

Analyzing the average obtained, accounting professionals are at 3.09 and students at 2.72 . The standard deviation of professionals is 1.117 and the standard deviation of students is 1.239 , thus the level of 
dispersion of answers obtained is higher among students. Confidence levels (95\%) for accounting professionals and students are only in the 'disagree or disagree' option. Professionals and prospective professionals have a tendency to diverge perceptions about the need for accounting to circumvent rules.

\section{B.13. The accounting profession can contribute to a more ethical society.}

The average of professionals is 4.13 and the average of students is 3.96. The standard deviation of accounting professionals is 0.848 and the standard deviation of students is 0.87 . The confidence interval (95\%) of both groups lies in the 'partially or often agree' option. Thus, accounting professionals and future professionals have differing perceptions. In the perception of accounting professionals, the accounting profession can contribute more to a more ethical society than the perception shown by students.

This hypothesis, accounting professionals and future professionals present different perceptions about professional ethics in accounting, is partially verified in the statements analyzed because there was a tendency to observe divergences in the perceptions of accounting professionals in relation to the perceptions of future professionals. The existence of this divergence is justified by the fact that accounting professionals effectively have knowledge of the reality in the profession, while students are based on expectations and future beliefs. Accounting professionals demonstrate that they have a stronger bond with the profession than that shown by students in accounting, and are justified by their professional career.

In short, in the field of professional ethics, it is possible to observe slight divergences between the trends of answers in the perspective of accounting professionals and in the perspective of future accounting professionals.

Table 1: Results in professional Ethics

\begin{tabular}{|c|c|c|c|c|c|c|c|c|}
\hline 8 & \multicolumn{4}{|c|}{ Professionals Accountants } & \multicolumn{4}{|c|}{ Accounting Students } \\
\hline Professional Ethics & $N$ & Average & Std. & $\begin{array}{l}\text { Conf. } \\
(95 \%)\end{array}$ & $N$ & Average & Std. & $\begin{array}{l}\text { Conf. } \\
(95 \%)\end{array}$ \\
\hline $\begin{array}{l}\text { B.2. The accountant can practice the } \\
\text { profession based on standards of } \\
\text { honesty and good faith. }\end{array}$ & 267 & 4,01 & 0,891 & [4-4] & 303 & 3,90 & 1,027 & [4-4] \\
\hline $\begin{array}{l}\text { B.3. The accountant can only accept } \\
\text { jobs he feels fit to perform. }\end{array}$ & 261 & 3,62 & 1,073 & [3-4] & 290 & 3,47 & 1,033 & [3-4] \\
\hline $\begin{array}{l}\text { B.4. The accountant manages to } \\
\text { maintain his technical independence } \\
\text { by distancing himself from personal } \\
\text { and external pressures. }\end{array}$ & 262 & 3,61 & 0,975 & [3-4] & 292 & 3,50 & 0,954 & [3-4] \\
\hline $\begin{array}{l}\text { B.5. The accounting officer has the } \\
\text { capacity to assume responsibility } \\
\text { for the duties performed. }\end{array}$ & 263 & 4,31 & 0,689 & [4-4] & 302 & 4,17 & 0,699 & [4-4] \\
\hline $\begin{array}{l}\text { B.7. The accountant manages to } \\
\text { exercise by keeping professional } \\
\text { secrecy of the facts and documents. }\end{array}$ & 266 & 4,45 & 0,776 & [4-5] & 302 & 4,26 & 0,775 & [4-4] \\
\hline $\begin{array}{l}\text { B.11. Since I entered accounting, } \\
\text { my values and those of the } \\
\text { profession have been approaching. }\end{array}$ & 252 & 3,88 & 0,829 & [4-4] & 253 & 3,75 & 0,899 & [4-4] \\
\hline $\begin{array}{l}\text { B.12. Sometimes in the profession } \\
\text { of accountant it is necessary to } \\
\text { circumvent the rules. }\end{array}$ & 256 & 3,09 & 1,117 & {$[3-3]$} & 267 & 2,72 & 1,239 & [2-3] \\
\hline $\begin{array}{l}\text { B.13. The accounting profession } \\
\text { can contribute to a more ethical } \\
\text { society. }\end{array}$ & 263 & 4,13 & 0,848 & [4-4] & 287 & 3,96 & 0,870 & [4-4] \\
\hline
\end{tabular}


Table 2 presents the distribution of results by scale. This scale has the following correspondence: 1 - never or strongly disagree; 2 - partially or rarely disagree; 3 - do not agree or disagree; 4 - totally or often agree; and finally 5 - totally or always agree.

Table 2: Results in Ethical Accounting Profession

\begin{tabular}{|c|c|c|c|c|c|c|}
\hline \multicolumn{2}{|l|}{ Ethical Accounting Profession } & \multirow{2}{*}{1} & \multirow[t]{2}{*}{2} & \multirow{2}{*}{$\frac{3}{40}$} & \multirow{2}{*}{$\frac{4}{144}$} & \multirow{2}{*}{$\begin{array}{c}5 \\
109\end{array}$} \\
\hline grity, & Freq. & & & & & \\
\hline $\begin{array}{l}\text { independence, responsibility, competence, } \\
\text { confidentiality, fairness and loyalty) defined by the }\end{array}$ & $\%$ & 0,0 & 2,3 & 13,3 & 48,0 & 36,3 \\
\hline $\begin{array}{l}\text { Order of Certified Accountants are in accordance with } \\
\text { mine. }\end{array}$ & & & & & & \\
\hline \multirow{2}{*}{$\begin{array}{l}\text { B.2. The accountant can practice the profession based } \\
\text { on standards of honesty and good faith. }\end{array}$} & Freq. & 5 & 17 & 50 & 143 & 85 \\
\hline & $\%$ & 1,7 & 5,7 & 16,7 & 47,7 & 28,3 \\
\hline \multirow{2}{*}{$\begin{array}{l}\text { B.3. The accountant can only accept jobs he feels fit } \\
\text { to perform. }\end{array}$} & Freq. & 7 & 34 & 78 & 120 & 61 \\
\hline & $\%$ & 2,3 & 11,3 & 26,0 & 40,0 & 20,3 \\
\hline \multirow{2}{*}{$\begin{array}{l}\text { B.4. The accountant manages to maintain his technical } \\
\text { independence by distancing himself from personal and } \\
\text { external pressures. }\end{array}$} & Freq. & 9 & 21 & 87 & 134 & 49 \\
\hline & $\%$ & 3,0 & 7,0 & 29,0 & 44,7 & 16,3 \\
\hline \multirow{2}{*}{$\begin{array}{l}\text { B.5. The accounting officer has the capacity to assume } \\
\text { responsibility for the duties performed. }\end{array}$} & Freq. & 0 & 3 & 41 & 148 & 108 \\
\hline & $\%$ & 0,0 & 1,0 & 13,7 & 49,3 & 36,0 \\
\hline \multirow{2}{*}{$\begin{array}{l}\text { B.6. The accounting officer is able to perform his } \\
\text { duties in compliance with the law, accounting } \\
\text { principles and ethical criteria. }\end{array}$} & Freq. & 2 & 6 & 36 & 143 & 113 \\
\hline & $\%$ & 0,7 & 2,0 & 12,0 & 47,7 & 37,7 \\
\hline \multirow{2}{*}{$\begin{array}{l}\text { B.7. The accountant manages to exercise by keeping } \\
\text { professional secrecy of the facts and documents. }\end{array}$} & Freq. & 2 & 3 & 32 & 111 & 152 \\
\hline & $\%$ & 0,7 & 1,0 & 10,7 & 37,0 & 50,7 \\
\hline \multirow{2}{*}{$\begin{array}{l}\text { B.8. The accountant can guarantee equal work and } \\
\text { attention to all his clients. }\end{array}$} & Freq. & 3 & 17 & 61 & 166 & 53 \\
\hline & $\%$ & 1,0 & 5,7 & 20,3 & 55,3 & 17,7 \\
\hline \multirow{2}{*}{$\begin{array}{l}\text { B.9. The accountant can dignify the profession by } \\
\text { acting in accordance with fair competition rules and } \\
\text { legal norms. }\end{array}$} & Freq. & 2 & 12 & 53 & 153 & 80 \\
\hline & $\%$ & 0,7 & 4,0 & 17,7 & 51,0 & 26,7 \\
\hline \multirow{2}{*}{$\begin{array}{l}\text { B.10. The accountant is able to exempt himself from } \\
\text { acts that are not within his professional competence. }\end{array}$} & Freq. & 6 & 29 & 82 & 135 & 48 \\
\hline & $\%$ & 2,0 & 9,7 & 27,3 & 45,0 & 16,0 \\
\hline \multirow{2}{*}{$\begin{array}{l}\text { B.11. Since I entered the field of accounting my } \\
\text { values and those of the profession have been } \\
\text { approaching. }\end{array}$} & Freq. & 5 & 9 & 71 & 158 & 57 \\
\hline & $\%$ & 1,7 & 3,0 & 23,7 & 52,7 & 19,0 \\
\hline \multirow{2}{*}{$\begin{array}{l}\text { B.12. Sometimes in the profession of accountant it is } \\
\text { necessary to circumvent the rules. }\end{array}$} & Freq. & 30 & 53 & 98 & 93 & 26 \\
\hline & $\%$ & 10,0 & 17,7 & 32,7 & 31,0 & 8,7 \\
\hline \multirow{2}{*}{$\begin{array}{l}\text { B.13. The accounting profession can contribute to a } \\
\text { more ethical society }\end{array}$} & Freq. & 4 & 11 & 52 & 143 & 90 \\
\hline & $\%$ & 1,3 & 3,7 & 17,3 & 47,7 & 30,0 \\
\hline
\end{tabular}

According to Maroco and Marques (2006), the internal consistency of the data corresponds to a measure of correlation between the different items in the same test. Internal consistency is applied through Cronbach's alpha, so it is measured if the various items under analysis have the same meaning. Internal consistency ranges from 0 to 1 . 
Professional ethics obtained a Cronbach's Alpha value of 0.819 for 13 items. The internal consistency values evaluated with Cronbach's alpha internal consistency coefficient are considered to be good because it is higher than 0.80 thus demonstrating good reliability in the collected data. In this mode the necessary condition is verified for the variables to be categorized by applying the same Likert scale, including the justification variables (Table 3).

Table 3: Cronbach's Alfa value

\begin{tabular}{|lcc|}
\hline & Cronbach's Alfa & No. of items \\
\hline Ethics & 0,819 & 13 \\
\hline
\end{tabular}

For statements about ethics in the accounting profession, accounting professionals and students have similar mean values and standard deviations. The average response rate for accounting professionals is 3.88 and for accounting students it is 3.86. In terms of standard deviation for professionals is 0.49 and for students is 0.48 .

In this hypothesis we intend to verify the level of divergence between the accounting professionals 'perceptions and the future professionals' perceptions about the accounting professional ethics. Professionals have higher ethical values than students although the difference is not statistically significant, $\mathrm{t}(298)=0.249, \mathrm{p}=0.804$. This does not prove the hypothesis stated. The hypothesis is not considered to be verified because there were no statistically significant differences between the perceptions of accounting professionals and future professionals in the field of professional ethics in accounting.

Table 4: Perceptions of ethics in the accounting profession

\begin{tabular}{|cccccccc|}
\hline & \multicolumn{2}{c}{ Professionals } & & \multicolumn{2}{c|}{ Students } & Sig. \\
\cline { 2 - 3 } & Average & Std & & Average & Std & \\
\hline $\begin{array}{c}\text { Ethics in the } \\
\text { accounting profession }\end{array}$ & 3,88 & 0,49 & & 3,86 & 0,48 & 0,804 \\
\hline
\end{tabular}

From the statistical test of the hypothesis it was not possible to prove statistically significant divergences between the perceptions of accounting professionals and future professionals regarding ethics in the practice of accounting.

\section{Conclusion}

It is possible to verify the existence of divergences between the investigated groups about the theme under study. The research question initially defined for the study showed that the perceptions of future accounting professionals differ partially compared to the perceptions shown by accounting professionals regarding ethics in the profession.

Following research on the confrontation of the perceptions of accounting professionals and future professionals (current students) within the scope of professional ethics in the exercise of the accounting profession. In this way, the perception of accounting professionals and the perception of future professionals regarding professional ethics are close, thus demonstrating that future professionals are knowledgeable and aware of the reality of professionals. Although it was expected that the perception of accounting professionals regarding professional ethics would be divergent compared to the perception of future professionals. it seems that accounting professionals know the reality of the accounting profession, while future professionals build future expectations.

For future research it is suggested to extend the study at national level to reach a global perspective of the accounting profession. And still select other topics of study in order to confront the optics of accounting professionals and future professionals. 
This research aims to contribute to the understanding of the perceptions between accounting professionals and future professionals, having as barriers of separation the reality of the labor market and professional experience.

\section{References}

Alves, F. J., Weffort, E. F., Lisboa, N. P. \& Antunes, M. T. (2007). Um estudo empírico sobre a importância do código de ética profissional para o contabilista. Revista Contabilidade \& Finanças, 43, 58-68.

Arruda, M. C., Whitaker, M. D., \& Ramos, J. M. (2001). Fundamentos da ética empresarial e econômica. São Paulo, Brasil: Atlas.

Chiavenato, I. (2004). Novas abordagens da administração. In nome do editor? (ed.) Introdução à teoria

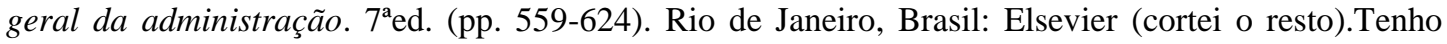
muitas dúvidas neste

Cortina, A., Conill, J., Moratalla, A. D., \& Marzá, V. D. G. (2005). Ética de la empresa: Claves para una nueva cultura empresarial. Cidade, EspanhaCastellano: Editorial Trotta.

Estatuto da Câmara dos Técnicos Oficiais de Contas 2015 _(PT) Decree Law No 139 (PT).

Glock, R. S. \& Goldim, J. R. (2003). Ética profissional é compromisso social. Retrieved from https://www.ufrgs.br/bioetica/eticprof.htm [05 fev, 2018].

Gonçalves, C., Carreira, F. (2012). O comportamento ético e o profissional de contabilidade. Lisboa, Portugal: Áreas Editora.

Gonçalves, C., Gonçalves, G., Sequeira, L. (2014). A profissão de técnico oficial de contas: Enquadramento normativo. Lisboa, Portugal: Vida Económica.

Lisboa, L. (1997). Ética geral e profissional em contabilidade (2a ed.).São Paulo, Brasil: Atlas.

Maroco, J. \& Marques,T. (2006). Qual a fiabilidade do alfa de Cronbach? Questões antigas e soluções modernas?. Retrived from http://publicacoes.ispa.pt/index.php/lp/article/viewFile/763/706 [2 Maio $2018]$.

Moreira, F. (2017). Contabilidade e ética no parlamento europeu. Contabilista, 204, 25.

Savater, F. (1998). Ética para um jovem. Retrived from https://pt.scribd.com/doc/257385676/Etica-paraum-Jovem-1-pdf [20 Set. 2017].

Vargas, R. (2005). Os meios justificam os fins: gestão baseada em valores da ética individual à ética empresarial. São Paulo, Brasil: Pearson Prentice Hall.

Vásquez, A. S. (1984). Ética. Retrived from http://pt.scribd.com/doc/57142809/Sanchez-Vazquez-AdolfoEtica-1969 [25 set, 2015]. 